\title{
Association between COX-2 rs2745557 polymorphism and prostate cancer risk: a systematic review and meta-analysis
}

\author{
Hongtuan Zhang ${ }^{1}$, Yong $\mathrm{Xu}^{1,2^{*}}$, Zhihong Zhang ${ }^{1}$, Ranlu Liu ${ }^{1}$ and Baojie Ma ${ }^{1}$
}

\begin{abstract}
Background: Evidence is accumulating that chronic inflammation may have an important role in prostate cancer (PCa). The COX-2 polymorphism rs2745557 (+202 C/T) has been extensively investigated as a potential risk factor for $\mathrm{PCa}$, but the results have thus far been inconclusive. This meta-analysis was performed to derive a more precise estimation of the association.

Methods: A comprehensive search was conducted to identify all case-control studies of COX-2 rs 2745557 polymorphism and PCa risk. We used odds ratios (ORs) to assess the strength of the association, and 95\% confidence intervals $(\mathrm{Cls})$ give a sense of the precision of the estimate. Statistical analyses were performed by Review Manage, version 5.0 and Stata 10.0.

Results: A total of 8 available studies were considered in the present meta-analysis, with 11356 patients and 11641 controls for rs2745557. When all groups were pooled, there was no evidence that rs27455557 had significant association with PCa under co-dominant, recessive, over-dominant, and allelic models. However, our analysis suggested that rs2745557 was associated with a lower PCa risk under dominant model in overall population $(\mathrm{OR}=$ $0.85,95 \% \mathrm{Cl}=0.74-0.97, \mathrm{P}=0.02$ ). When stratifying for race, there was a significant association between rs 2745557 polymorphism and lower PCa risk in dominant model comparison in the subgroup of Caucasians (OR $=0.86,95 \%$ $\mathrm{Cl}=0.75-0.99, \mathrm{P}=0.04$ ), but not in co-dominant, recessive, over-dominant and allelic comparisons.
\end{abstract}

Conclusion: Based on our meta-analysis, COX-2 rs2745557 was associated with a lower PCa risk under dominant model in Caucasians.

\section{Background}

$\mathrm{PCa}$ is one of the most frequently diagnosed malignancies and a common cause of cancer mortality in men in the Western hemisphere [1,2]. Identifying risk factors for PCa is critically important to develop potential interventions and to expand our understanding of the biology of this disease. Despite the fact that the complex etiology of PCa remains obscure, various risk factors play an important role in PCa development such as advanced age, environmental variations, culture changes, and genetic variations. A strong association exists between states of chronic inflammation and cancer, and it is believed that mediators of inflammation

\footnotetext{
* Correspondence: xymnwk@163.com

'Department of Urology, Second Hospital of Tianjin Medical University,

Tianjin Institute of Urology, Tianjin, China

Full list of author information is available at the end of the article
}

may be responsible for this phenomenon [3]. Chronic inflammation may lead to tumorigenesis by damaging DNA through radical oxygen and nitrogen species, enhancing cell proliferation, and stimulating angiogenesis [4]. Some single nucleotide polymorphisms in specific cytokine genes have been proved to influence the expression and/or activity of encoding proteins probably making thereby the host predispose to certain cancer [5-7], so rs 2745557 polymorphism of COX-2 that involved in the inflammatory pathway might impact susceptibility to PCa.

COX, also known as prostaglandin-endoperoxide synthase (PTGS), catalyzes the rate-limiting step in the formation of inflammatory prostaglandins. COX is an integral membrane bifunctional enzyme, which metabolizes arachidonic acids to many biologically active eicosanoids. COX-2 gene located on chromosome 
1q25.2-q25.3 is a candidate gene for PCa susceptibility [8]. COX-2 is an inducible enzyme that converts arachidonic acid to prostaglandins, which play a role in cell proliferation and are potent mediators of inflammation. A meta-analysis suggested that aspirin use was associated a trend of decreased PCa risk [9]. The data suggested that COX-2 is overexpressed in $\mathrm{PCa}$ tissue compared to benign tissue from the same patient in several studies [10-14]. Some previous studies suggested that COX-2 may influence carcinogenesis by inhibiting apoptosis [15], inducing angiogenesis [16] and by chronic activation of immune responses [17].

Several polymorphisms in the COX-2 gene have been described, such as rs5277, rs689466, rs2206593, rs689470, and rs2745557. rs2745557 polymorphism in intron 1 has been brought to our attention. The functional impact of rs2745557, an intronic variant, on COX-2 activity is not yet known. Several studies were conducted to investigate the associations of COX-2 rs2745557 with PCa susceptibility [18-24]. However, molecular epidemiological studies have yielded contradictory results concerning potential roles of rs2745557 polymorphism in $\mathrm{PCa}$. Individual studies might have been underpowered to detect the overall effects. Some studies are limited by their sample size and subsequently suffer from too low power to detect effects that may exist. Given the amount of accumulated data, we deemed it important to perform a quantitative synthesis of the evidence. Therefore, we performed this meta-analysis study to determine whether COX-2 rs2745557 was associated with PCa risk.

\section{Methods}

\section{Literature search}

We searched the articles using the terms "COX-2" or "PTGS2", "prostate", "carcinoma" or "cancer" or "tumor", and "polymorphism" or "variation" in PubMed, Cochrane Library and Embase electronic databases, and all eligible studies were published before November 15, 2011. We evaluated all associated publications to retrieve the most eligible literatures. The reference lists of reviews and retrieved articles were hand searched at the same time. We did not include abstracts or unpublished reports. When overlapping data of the same patient population were included in more than one publication, only the most recent or complete study was used in this meta-analysis. Articles were limited to English language papers.

\section{Inclusion and exclusion criteria}

The following inclusion criteria were used to select literatures for the meta-analysis: (1) information on the evaluation of COX-2 rs2745557 polymorphism and PCa susceptibility; (2) case-control studies; and (3) sufficient genotype data were presented to calculate the OR with 95\% CI. Major reasons for exclusion of studies were: (1) no controls; (2) reviews and duplication of the previous publication; and (3) no usable data reported.

\section{Data extraction}

All data were extracted independently by two investigators according to the prespecified selection criteria. Disagreement was resolved by discussion. The following data were extracted: the name of the first author, publication year, ethnicity of the population, available genotype, number of prostate cancer cases and controls studied and results of studies. Different descents were categorized as Caucasian, Asian, and African American. For case-control studies, data were extracted separately for each group whenever possible.

\section{Statistical analysis}

The strength of the association between COX-2 rs2745557 polymorphism and PCa risk was measured by ORs, whereas a sense of the precision of the estimate was given by $95 \%$ CIs. The significance of the summary OR was determined with a Z-test. We first examined rs2745557 genotypes using co-dominant model (homogeneous co-dominant model: TT vs CC, heterogeneous co-dominant model: TC vs CC), recessive (TT vs TC + $\mathrm{CC}$ ), over-dominant (TC vs TT $+\mathrm{CC}$ ) and dominant ( TT + TC vs CC) genetic models. Then, the relationship between the allele and susceptibility to $\mathrm{PCa}$ was examined (allelic model). Stratified analyses were also performed by ethnicities. A chi-square-based Q-statistic test and an $\mathrm{I}^{2}$-test test were both performed to evaluate the between-study heterogeneity of the studies. In our study, two models of meta-analysis were applied for dichotomous outcomes: the fixed-effects model and the random-effects model. The fixed-effects model assumes that studies are sampled from populations with the same effect size, making an adjustment to the study weights according to the in-study variance. The random-effects model assumes that studies are taken from populations with varying effect sizes, calculating the study weights both from in-study and between-study variances, considering the extent of variation, or heterogeneity. A P-value $\geq 0.10$ for the Q-test indicated lack of heterogeneity among the studies, and so the summary OR estimate of each study was calculated by the fixedeffects model [25]. Otherwise, the random-effects model (DerSimonian and Laird method) was used [26]. $\mathrm{I}^{2}$ statistic can be used to quantify heterogeneity irrespective of the number of studies.

The significance of the pooled OR was determined by the Z-test and $\mathrm{P}<0.05$ was considered as statistically significant. To explore the reasons of heterogeneity, subgroup analyses were performed by ethnicity. 
The one-way sensitivity analyses were performed to assess the stability of the results, namely, a single study in the meta-analysis was deleted each time to reflect the influence of the individual data set to the pooled OR. To investigate whether publication bias might affect the validity of the estimates, funnel plot were constructed. An asymmetric plot suggests a possible publication bias. Funnel plot asymmetry was assessed by the method of Egger's linear regression test, a linear regression approach to measure funnel plot asymmetry on the natural logarithm scale of OR. The significance of the intercept was determined by the $\mathrm{t}$-test suggested by Egger ( $\mathrm{P}$ $<0.05$ was considered representative of statistically significant publication bias). All statistical tests were performed with Review Manage, version 5.0 and Stata 10.0 using two-sided P-values.

\section{Results \\ Eligible studies}

According to the inclusion criteria defined above, we identified 8 independent studies in 7 eligible reports [18-24], including 11356 cases and 11641 controls. All the included 8 eligible reports were written in English. 8 independent studies consisted of 1 Asian, 1 African American and 6 Caucasian populations. 2 studies included in the subgroup analysis of Caucasians also contained a relevant proportion of subjects was not Caucasian [20,21]. Main characteristics for all eligible studies were listed in Table 1.

\section{Meta-analyses}

In overall population, there was significant heterogeneity in COX-2 rs2745557 for dominant model comparison, heterogeneous co-dominant model, over-dominant model and allelic model comparison, except for the homogeneous co-dominant model and recessive model comparisons. After subgroup analyses by ethnicity, the heterogeneity was effectively removed under allelic model in Caucasians. The data suggested that rs 2745557 was associated with a lower PCa risk under dominant model in overall population $(\mathrm{OR}=0.85,95 \% \mathrm{CI}=0.74$ $0.97, \mathrm{P}=0.02$; Figure 1). However, we did not detect the association between rs2745557 polymorphism and PCa risk in overall population when examining the contrast of TT versus $C C, \mathrm{TC}$ versus $\mathrm{CC}$, TT versus $\mathrm{TC}+$ $\mathrm{CC}, \mathrm{TC}$ versus $\mathrm{TT}+\mathrm{CC}$, and $\mathrm{T}$ allele versus $\mathrm{C}$ allele $(\mathrm{OR}=1.04,95 \% \mathrm{CI}=0.88-1.23, \mathrm{P}=0.66$; $\mathrm{OR}=0.88$, $95 \% \mathrm{CI}=0.74-1.04, \mathrm{P}=0.14 ; \mathrm{OR}=1.06,95 \% \mathrm{CI}=$ $0.89-1.25, \mathrm{P}=0.51 ; \mathrm{OR}=0.88,95 \% \mathrm{CI}=0.75-1.04, \mathrm{P}=$ 0.13 ; and $\mathrm{OR}=0.92,95 \% \mathrm{CI}=0.80-1.06, \mathrm{P}=0.26$, respectively). Similarly, in subgroup analyses stratified by ethnicity, the remarkable association with lower PCa risk was detected in dominant model comparison in Caucasian population $(\mathrm{OR}=0.86,95 \% \mathrm{CI}=0.75-0.99, \mathrm{P}=$ 0.04; Figure 2). No noteworthy associations were observed under co-dominant, recessive, over-dominant, and allelic models in Caucasians. The detailed data were presented in Table 2.

\section{Sensitivity analysis}

In order to compare the difference and evaluate the sensitivity of the meta-analyses, we conducted one-way sensitivity analysis to evaluate the stability of the metaanalysis. The statistical significance of the results was not altered when any single study was omitted (data not shown), confirming the stability of the results. Hence,

Table 1 Main characteristics of studies included in this meta-analysis

\begin{tabular}{|c|c|c|c|c|c|c|c|c|c|c|c|c|c|}
\hline \multirow[t]{2}{*}{$\begin{array}{l}\text { First } \\
\text { author }\end{array}$} & \multirow[t]{2}{*}{ Year } & \multirow[t]{2}{*}{ Country } & \multirow[t]{2}{*}{ Cases } & \multirow[t]{2}{*}{ Controls } & \multirow[t]{2}{*}{ Ethnicity } & \multicolumn{4}{|c|}{$\begin{array}{l}\text { rs2745557 } \\
\text { cases }\end{array}$} & \multicolumn{4}{|c|}{$\begin{array}{l}\text { rs } 2745557 \\
\text { controls }\end{array}$} \\
\hline & & & & & & $\begin{array}{l}\mathrm{CC} \\
(\%)\end{array}$ & $\begin{array}{l}\mathrm{TC} \\
(\%)\end{array}$ & $\begin{array}{l}\mathrm{TC}+ \\
\mathrm{TT}(\%)\end{array}$ & $\begin{array}{l}\mathrm{TT} \\
(\%)\end{array}$ & $\begin{array}{l}\mathrm{CC} \\
(\%)\end{array}$ & $\begin{array}{l}\mathrm{TC} \\
(\%)\end{array}$ & $\begin{array}{l}\text { TC }+ \\
\text { TT }(\%)\end{array}$ & $\begin{array}{l}\mathrm{TT} \\
(\%)\end{array}$ \\
\hline $\begin{array}{l}\text { Wu et } \\
\text { al. }\end{array}$ & 2011 & China & 218 & 436 & Asian & $\begin{array}{l}165 \\
(75.7)\end{array}$ & $\begin{array}{l}49 \\
(22.5)\end{array}$ & $53(24.3)$ & $4(1.8)$ & $\begin{array}{l}320 \\
(73.4)\end{array}$ & $\begin{array}{l}107 \\
(24.5)\end{array}$ & $\begin{array}{l}116 \\
(26.6)\end{array}$ & $\begin{array}{l}9 \\
(2.1)\end{array}$ \\
\hline $\begin{array}{l}\text { Amirian } \\
\text { et al. }\end{array}$ & 2011 & USA & 535 & 533 & Caucasian & $\begin{array}{l}372 \\
(69.5)\end{array}$ & & $\begin{array}{l}163 \\
(30.5)\end{array}$ & & $\begin{array}{l}353 \\
(66.2)\end{array}$ & & $\begin{array}{l}180 \\
(33.8)\end{array}$ & \\
\hline $\begin{array}{l}\text { Salinas } \\
\text { et al. }\end{array}$ & 2010 & USA & 335 & 396 & Caucasian & $\begin{array}{l}225 \\
(67.2)\end{array}$ & & $\begin{array}{l}110 \\
(32.8)\end{array}$ & & $\begin{array}{l}251 \\
(63.4)\end{array}$ & & $\begin{array}{l}145 \\
(36.7)\end{array}$ & \\
\hline $\begin{array}{l}\text { Fradet } \\
\text { et al. }\end{array}$ & 2009 & USA & 466 & 478 & Caucasian (83\%), African American & $\begin{array}{l}337 \\
(72.3)\end{array}$ & & $\begin{array}{l}129 \\
(27.7)\end{array}$ & & $\begin{array}{l}301 \\
(63.0)\end{array}$ & & $\begin{array}{l}177 \\
(37.0)\end{array}$ & \\
\hline $\begin{array}{l}\text { Dossus } \\
\text { et al. }\end{array}$ & 2009 & $\begin{array}{l}\text { USA } \\
\text { Europe }\end{array}$ & 7941 & 8527 & $\begin{array}{c}\text { Caucasian, African-American, Latino, } \\
\text { native Hawaiian, Asian }\end{array}$ & $\begin{array}{l}5614 \\
(70.7)\end{array}$ & $\begin{array}{l}2098 \\
(26.4)\end{array}$ & $\begin{array}{l}2327 \\
(29.3)\end{array}$ & $\begin{array}{l}229 \\
(28.8)\end{array}$ & $\begin{array}{l}5954 \\
(69.9)\end{array}$ & $\begin{array}{l}2338 \\
(27.4)\end{array}$ & $\begin{array}{l}2573 \\
(30.2)\end{array}$ & $\begin{array}{l}235 \\
(2.8)\end{array}$ \\
\hline $\begin{array}{l}\text { Cheng } \\
\text { et al. }\end{array}$ & 2007 & USA & 89 & 89 & African American & $\begin{array}{l}69 \\
(77.5)\end{array}$ & $\begin{array}{l}19 \\
(21.3)\end{array}$ & 20(22.5) & $1(1.1)$ & $\begin{array}{l}56 \\
(63.0)\end{array}$ & $\begin{array}{l}30 \\
(33.7)\end{array}$ & $33(37.1)$ & $\begin{array}{l}3 \\
(3.4)\end{array}$ \\
\hline $\begin{array}{l}\text { Cheng } \\
\text { et al. }\end{array}$ & 2007 & USA & 417 & 417 & Caucasian & $\begin{array}{l}295 \\
(70.7)\end{array}$ & $\begin{array}{l}107 \\
(25.7)\end{array}$ & $\begin{array}{l}122 \\
(29.3)\end{array}$ & $\begin{array}{l}15 \\
(36.0)\end{array}$ & $\begin{array}{l}262 \\
(62.8)\end{array}$ & $\begin{array}{l}142 \\
(34.1)\end{array}$ & $\begin{array}{l}155 \\
(37.2)\end{array}$ & $\begin{array}{l}13 \\
(3.1)\end{array}$ \\
\hline $\begin{array}{l}\text { Shahedi } \\
\text { et al. }\end{array}$ & 2006 & Sweden & 1355 & 765 & Caucasian & $\begin{array}{l}945 \\
(69.7)\end{array}$ & $\begin{array}{l}376 \\
(27.7)\end{array}$ & $\begin{array}{l}410 \\
(30.3)\end{array}$ & $\begin{array}{l}34 \\
(2.5)\end{array}$ & $\begin{array}{l}545 \\
(71.2)\end{array}$ & $\begin{array}{l}205 \\
(26.8)\end{array}$ & $\begin{array}{l}220 \\
(28.8)\end{array}$ & $\begin{array}{l}15 \\
(2.0)\end{array}$ \\
\hline
\end{tabular}




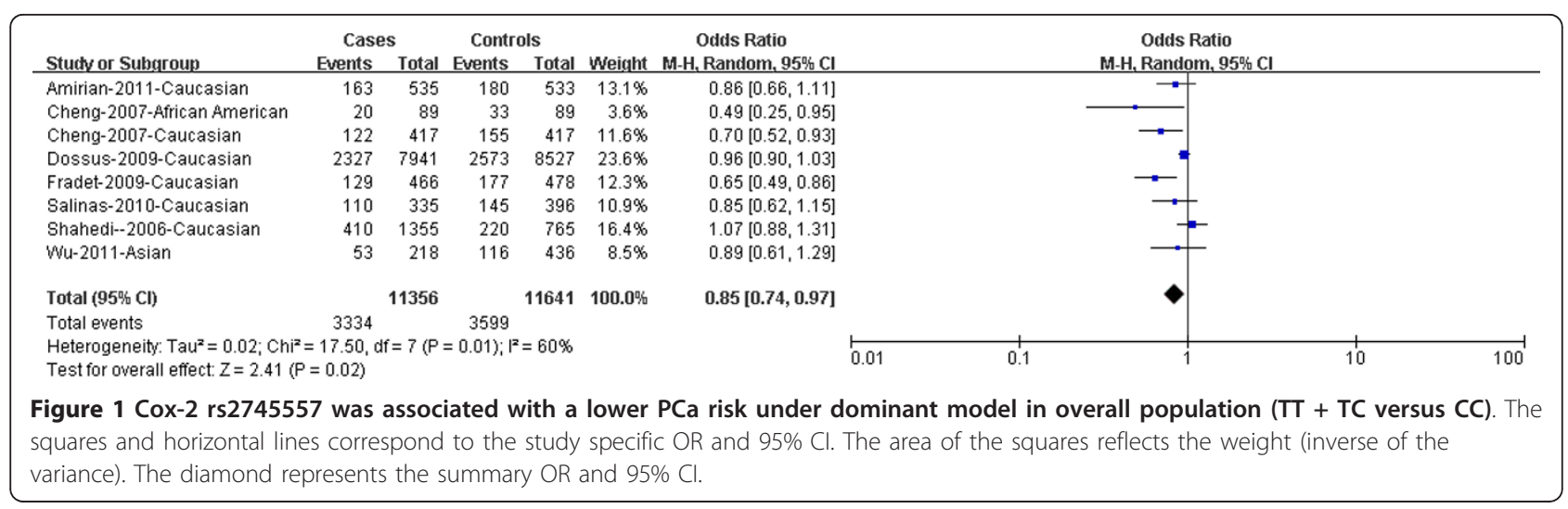

results of the sensitivity analysis suggest that the data in this meta-analysis are relatively stable and credible.

\section{Publication bias}

Begg's funnel plot and Egger's test were performed to assess the publication bias. The shape of funnel plots did not reveal any evidence of obvious asymmetry in all comparison models, and the Egger's test was used to provide statistical evidence of funnel plot symmetry. The results did not show any evidence of publication bias. The detailed data were present in Table 2 .

\section{Discussion}

We consider the COX-2 gene highly interesting in the search for susceptibility genes for PCa. Previous study results suggested that single nucleotide polymorphisms (SNPs) are the most common sources of human genetic variation, and they may contribute to an individual's susceptibility to cancer [27]. In the recent years, interest in the genetic susceptibility to cancers has led to a growing attention to the study of polymorphisms of genes involved in tumourigenesis. Since the identification of COX-2 rs2745557 polymorphism, growing number of studies suggested that COX-2 rs2745557 polymorphism plays an important role in the development of PCa. Epidemiological studies of the rs2745557 polymorphism in COX-2, if large and unbiased, can provide insight into the in vivo relationship between the gene and $\mathrm{PCa}$ risk. However, these studies have appeared in the literature either supporting or negating the significant association. Some reviewed studies are limited by their sample size and subsequently suffer from too low power to detect effects that may exist. But the pool ORs generated from much larger population can increase the statistical power. Combining data from many studies has the advantage of reducing random error [28].

In order to provide the comprehensive and reliable conclusion, we performed the present meta-analysis of 8 independent case-control studies [18-24], including 11356 patients and 11641 controls. According to the study design, 3 studies were conducted in a populationbased design [20,22,24], and 5 in a hospital-based design $[18,19,21,23]$. Some studies reported insufficient information about recruitment methodology and study participant characteristics, particularly for controls. The control populations were not uniform. Healthy populations as well as non-cancer patients were included. Some individuals in the control group are likely to develop cancer in subsequent years though they had no clinical symptoms at the time of investigation. Our results indicated that the rs2745557 was associated with

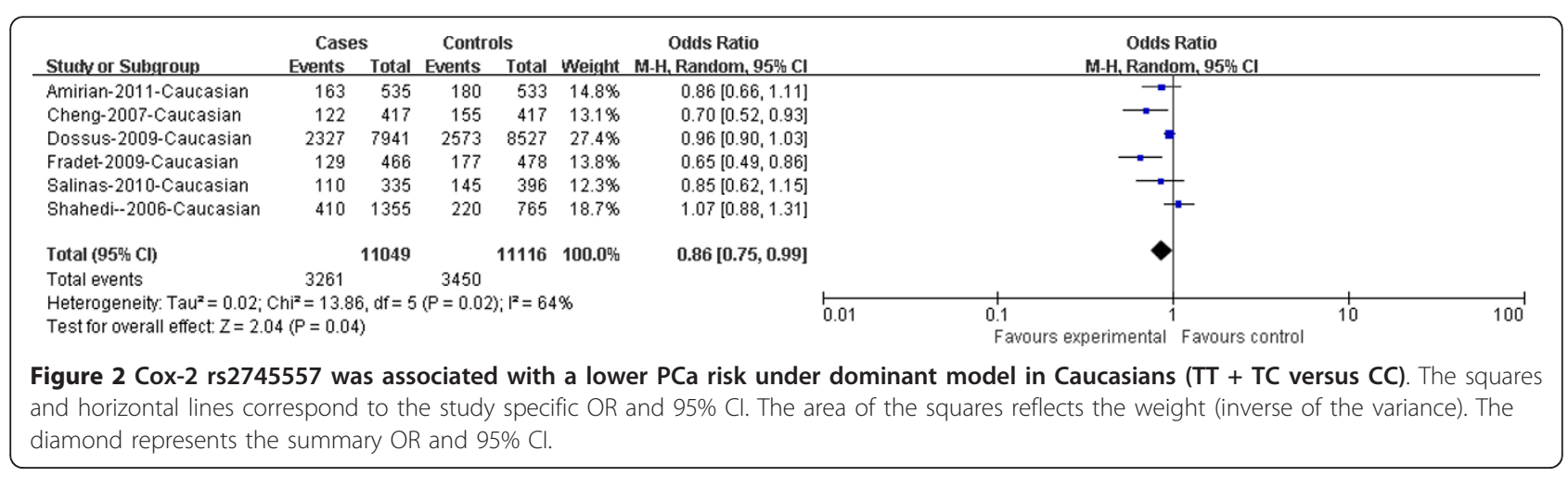


Table 2 Meta-Analysis of COX-2 rs2745557 Polymorphisms and Prostate Cancer

\begin{tabular}{|c|c|c|c|c|c|c|c|c|}
\hline \multirow{2}{*}{$\begin{array}{l}\text { Genetic model } \\
\text { (No. of studies) }\end{array}$} & \multicolumn{2}{|c|}{ Sample size } & \multirow[t]{2}{*}{ Analysis model } & \multicolumn{2}{|l|}{ Test of association } & \multirow[t]{2}{*}{$P$ value for Egger's test } & \multicolumn{2}{|c|}{ Test for heterogeneity } \\
\hline & Case & Control & & OR $(95 \% \mathrm{CI})$ & $P$ & & $P$ & $1^{2}$ \\
\hline \multicolumn{9}{|l|}{ Total (8) } \\
\hline TT vs CC (5) & 7371 & 7412 & $\mathrm{~F}$ & $1.04(0.88-1.23)$ & 0.66 & 0.510 & 0.74 & $0 \%$ \\
\hline TC vs CC (5) & 9737 & 9959 & $\mathrm{R}$ & $0.88(0.74-1.04)$ & 0.14 & 0.275 & 0.05 & $58 \%$ \\
\hline TT vs TC + CC (5) & 10020 & 10234 & $\mathrm{~F}$ & $1.06(0.89-1.25)$ & 0.51 & 0.627 & 0.81 & $0 \%$ \\
\hline$\pi+T C$ vs CC (8) & 11356 & 11641 & R & $0.85(0.74-0.97)$ & 0.02 & 0.062 & 0.01 & $60 \%$ \\
\hline TC vs TT + CC (5) & 10020 & 10234 & R & $0.88(0.75-1.04)$ & 0.13 & 0.276 & 0.06 & $56 \%$ \\
\hline T vs C (5) & 20040 & 20468 & R & $0.92(0.80-1.06)$ & 0.26 & 0.284 & 0.07 & $55 \%$ \\
\hline \multicolumn{9}{|l|}{ Caucasian (6) } \\
\hline TT vs CC (3) & 7132 & 7024 & $\mathrm{~F}$ & $1.05(0.89-1.25)$ & 0.56 & & 0.77 & $0 \%$ \\
\hline TC vs CC (3) & 9435 & 9446 & $\mathrm{R}$ & $0.91(0.76-1.10)$ & 0.33 & & 0.04 & $68 \%$ \\
\hline TT vs TC + CC (3) & 9713 & 9709 & F & $1.07(0.90-1.27)$ & 0.43 & & 0.80 & $0 \%$ \\
\hline TT+TC vs CC (6) & 11049 & 11116 & $\mathrm{R}$ & $0.86(0.75-0.99)$ & 0.04 & & 0.02 & $64 \%$ \\
\hline TC vs TT + CC (3) & 9713 & 9709 & $\mathrm{R}$ & $0.91(0.76-1.09)$ & 0.31 & & 0.04 & $68 \%$ \\
\hline T vs C (3) & 19426 & 19418 & $\mathrm{~F}$ & $0.97(0.92-1.03)$ & 0.32 & & 0.11 & $55 \%$ \\
\hline
\end{tabular}

OR odds ratio, $\mathrm{Cl}$ confidence interval, vs versus, $R$, random effect model, $F$, fixed effect model

a lower PCa risk under dominant model in overall population. Nevertheless, considering that rs2745557 polymorphism may play different roles in PCa susceptibility among different ethnic subgroups and the frequencies of rs2745557 polymorphism might be different among different ethnic groups which might contribute to the possible presence of heterogeneity between the studies, we further conducted subgroup analysis by ethnicity in current meta-analysis. In the stratified analysis by ethnicity, our results suggested that COX-2 rs2745557 polymorphism was associated with a lower PCa risk among subjects of Caucasians. We found that COX-2 rs2745557 polymorphism was associated with a trend of decreased PCa risk under dominant model and allelic model in African Americans, however significant relation was absent in Asians. There may be many factors influencing the result, such as differences in populations, selection factors and so on. The rs2745557 was associated with a lower PCa risk under dominant model. However, the significant association is completely lost under homogeneous co-dominant model or allelic model. So we can speculate that rs2745557 may associate with a lower PCa risk under over-dominant model. However, the significant association was absent. The reason for this phenomenon may be caused by a lack of sufficient genotype data in several studies. Considering the limited studies and population numbers of African Americans and Asians included in the meta-analysis, this may increase the risk of false negative findings, any conclusions at overall population level should be interpreted with caution. Therefore, we are not sure whether there is a significant association between the COX-2 polymorphism and decreased PCa risk in the whole population due to low statistical power.

Heterogeneity is a potential problem when interpreting the results of the present meta-analysis. In overall analysis, significant between-study heterogeneity existed in dominant model, heterogeneous co-dominant model, over-dominant model and allelic model comparisons. After subgroup analyses by ethnicity, the heterogeneity was removed under allelic model in Caucasians. In this meta-analysis, high levels of heterogeneity were observed in some comparisons. There are some factors that could have contributed toward the high heterogeneity. First, there is likely to be considerable genetic heterogeneity between the samples that were drawn from geographically diverse populations. It is known that genotype distributions differ across populations, and genotypephenotype associations may also depend on population stratification. Second, definition of control group is different in different studies, the definition differences of the controls could have contributed to the high heterogeneity observed in our meta-analysis. Third, we attempted to determine if the high heterogeneity might also be explained by other variables such as stages of $\mathrm{PCa}$, smoking status, and environmental factors included in the different studies, but are unable to provide a reliable answer to this question because we did not have access to individual level data for these variables.

Some limitations of this meta-analysis should be acknowledged. First, because only published and English articles were included in the meta-analysis, publication and potential English language biases may have occurred, even though it was not found by making use 
of statistical test. Second, the result should be cautiously interpreted because controls were not uniformly defined. Non-differential misclassification bias was possible because these studies may have included controls that had different risks for developing PCa. Third, only one study analyzed Asian population and another one African American population in this study. So it is quite important to have more studies and sample of Asians, Africans, and African Americans in the future so that more precise conclusion about the associations between rs2745557 polymorphism and PCa risk could be achieved. Fourth, our results were based on unadjusted estimates, while a more precise analysis should be conducted adjusted by other factors like smoking, drinking status and environmental factors. In addition, our analysis did not consider the possibility of gene-gene or SNPSNP interactions or the possibility of linkage disequilibrium between polymorphisms. Further investigations of the haplotypic effect of a gene and the study of multiple polymorphisms in different genes are needed.

\section{Conclusions}

In conclusion, our meta-analysis suggested that there was an association between rs2745557 polymorphism and lower PCa risk in Caucasians. Due to limitations showed above in this analysis, it is critical that larger and well-designed multicenter studies are needed to confirm our results.

\section{Abbreviations}

PCa: Prostate cancer; PTGS: Prostaglandin-endoperoxide synthase; OR: odds ratio; Cl: Confidence interval; vs: Versus; R: Random effect model; F: Fixed effect model.

\section{Acknowledgements}

This study was supported by Science Foundation of Tianjin medical university. (NO: 2009GSI18)

\section{Author details}

${ }^{1}$ Department of Urology, Second Hospital of Tianjin Medical University, Tianjin Institute of Urology, Tianjin, China. ${ }^{2}$ Department of Urology, Second Hospital of Tianjin Medical University, 23 Pingjiang Road, Hexi District, Tianjin 300211, China.

\section{Authors' contributions}

$\mathrm{ZH}$ carried out the publication search, participated in data analysis and drafted the manuscript. XY carried out publication search, and revised the manuscript. ZZ and LR participated in the publication search and helped to draft the manuscript. MB participated performed the statistical analysis. All authors read and approved the final manuscript.

\section{Competing interests}

The authors declare that they have no competing interests.

Received: 19 December 2011 Accepted: 21 March 2012

Published: 21 March 2012

\section{References}

1. Jemal A, Siegel R, Xu J, Ward E: Cancer statistics, 2010. CA Cancer J Clin $2010,60: 277-300$.
2. Siegel R, Ward E, Brawley O, Jemal A: Cancer statistics, 2011. CA Cancer J Clin 2011, 61:212-236.

3. Shacter E, Weitzman SA: Chronic inflammation and cancer. Oncology 2002, 16:217-226.

4. McArdle PA, Mir K, Almushatat AS, Wallace AM, Underwood MA, McMillan DC: Systemic inflammatory response, prostate-specific antigen and survival in patients with metastatic prostate cancer. Urol Int 2006, 77:127-129.

5. Mosser DM, Zhang $X$ : Interleukin-10: new perspectives on an old cytokine. Immunol Rev 2008, 226:205-218.

6. Serefoglou Z, Yapijakis C, Nkenke E, Vairaktaris E: Genetic association of cytokine DNA polymorphisms with head and neck cancer. Oral Oncol 2008, 44:1093-1099.

7. Howell WM, Rose-Zerilli MJ: Cytokine gene polymorphisms, cancer susceptibility, and prognosis. J Nutr 2007, 137:194-199.

8. Kosaka T, Miyata A, Ihara H, Hara S, Sugimoto T, Takeda O, Takahashi E, Tanabe T: Characterization of the human gene (PTGS2) encoding prostaglandin-endoperoxide synthase 2. Eur J Biochem 1994, 221:889-897.

9. Mahmud S, Franco E, Aprikian A: Prostate cancer and use of nonsteroidal anti-inflammatory drugs: systematic review and meta-analysis. $\mathrm{Br} J$ Cancer 2004, 90:93-99.

10. Madaan S, Abel PD, Chaudhary KS, Hewitt R, Stott MA, Stamp GW, Lalani EN: Cytoplasmic induction and over-expression of cyclooxygenase2 in human prostate cancer: implications for prevention and treatment. BJU Int 2000, 86:736-741.

11. Denkert C, Thoma A, Niesporek S, Weichert W, Koch I, Noske A, Schicktanz H, Burkhardt M, Jung K, Dietel M, Kristiansen G: Overexpression of cyclooxygenase-2 in human prostate carcinoma and prostatic intraepithelial neoplasia-association with increased expression of Pololike kinase-1. Prostate 2007, 67:361-369.

12. Gupta S, Srivastava M, Ahmad N, Bostwick DG, Mukhtar H: Over-expression of cyclooxygenase-2 in human prostate adenocarcinoma. Prostate 2000, 42:73-78.

13. Kirschenbaum A, Klausner AP, Lee $R$, Unger $P$, Yao S, Liu XH, Levine AC: Expression of cyclooxygenase- 1 and cyclooxygenase- 2 in the human prostate. Urology 2000, 56:671-676.

14. Uotila $P$, Valve $E$, Martikainen $P$, Nevalainen $M$, Nurmi $M$, Härkönen $P$ : Increased expression of cyclooxygenase- 2 and nitric oxide synthase-2 in human prostate cancer. Urol Res 2001, 29:23-28.

15. Tsujii M, DuBois RN: Alterations in cellular adhesion and apoptosis in epithelial cells overexpressing prostaglandin endoperoxide synthase 2 . Cell 1995, 83:493-501.

16. Masferrer JL, Leahy KM, Koki AT, Zweifel BS, Settle SL, Woerner BM, Edwards DA, Flickinger AG, Moore RJ, Seibert K: Antiangiogenic and antitumor activities of cyclooxygenase-2 inhibitors. Cancer Res 2000 60:1306-1311.

17. O'Byrne KJ, Dalgleish AG: Chronic immune activation and inflammation as the cause of malignancy. Br J Cancer 2001, 85:473-483.

18. Wu HC, Chang CH, Ke HL, Chang WS, Cheng HN, Lin HH, Wu CY, Tsai CW, Tsai RY, Lo WC, Bau DT: Association of cyclooxygenase 2 polymorphic genotypes with prostate cancer in taiwan. Anticancer Res 2011, 31:221-225.

19. Amirian ES, Ittmann MM, Scheurer ME: Associations between arachidonic acid metabolism gene polymorphisms and prostate cancer risk. Prostate 2011, 71:1382-9.

20. Salinas CA, Kwon EM, FitzGerald LM, Feng Z, Nelson PS, Ostrander EA, Peters U, Stanford JL: Use of aspirin and other nonsteroidal antiinflammatory medications in relation to prostate cancer risk. Am J Epidemiol 2010, 172:578-590.

21. Fradet V, Cheng I, Casey G, Witte JS: Dietary omega-3 fatty acids, cyclooxygenase- 2 genetic variation, and aggressive prostate cancer risk. Clin Cancer Res 2009, 15:2559-2566.

22. Dossus L, Kaaks R, Canzian F, Albanes D, Berndt SI, Boeing H, Buring J, Chanock SJ, Clavel-Chapelon F, Feigelson HS, Gaziano JM, Giovannucci E, Gonzalez C, Haiman CA, Hallmans G, Hankinson SE, Hayes RB, Henderson BE, Hoover RN, Hunter DJ, Khaw KT, Kolonel LN, Kraft P, Ma J, Le Marchand L, Lund E, Peeters PH, Stampfer M, Stram DO, Thomas G, Thun MJ, Tjonneland A, Trichopoulos D, Tumino R, Riboli E, Virtamo J, Weinstein SJ, Yeager M, Ziegler RG, Cox DG: PTGS2 and IL6 genetic variation and risk of breast and prostate cancer: results from the Breast 
and Prostate Cancer Cohort Consortium (BPC3). Carcinogenesis 2010, 31:455-461.

23. Cheng I, Liu X, Plummer SJ, Krumroy LM, Casey G, Witte JS: COX2 genetic variation, NSAIDs, and advanced prostate cancer risk. Br J Cancer 2007, 97:557-561.

24. Shahedi K, Lindström S, Zheng SL, Wiklund F, Adolfsson J, Sun J, Augustsson-Bälter K, Chang BL, Adami HO, Liu W, Grönberg H, Xu J: Genetic variation in the COX-2 gene and the association with prostate cancer risk. Int I Cancer 2006, 119:668-672.

25. Mantel N, Haenszel W: Statistical aspects of the analysis of data from retrospective studies of disease. J Natl Cancer Inst 1959, 22:719-748.

26. DerSimonian R, Laird N: Meta-analysis in clinical trials. Control Clin Trials 1986, 7:177-188.

27. Wu GY, Hasenberg T, Magdeburg R, Bönninghoff R, Sturm JW, Keese M: Association between EGF, TGF-beta1, VEGF gene polymorphism and colorectal cancer. World J Surg 2009, 33:124-129.

28. Ioannidis JP, Boffetta P, Little J, O'Brien TR, Uitterlinden AG, Vineis $P$, Balding DJ, Chokkalingam A, Dolan SM, Flanders WD, Higgins JP, McCarthy MI, McDermott DH, Page GP, Rebbeck TR, Seminara D, Khoury MJ: Assessment of cumulative evidence on genetic associations: interim guidelines. Int J Epidemiol 2008, 37:120-132.

doi:10.1186/1471-2172-13-14

Cite this article as: Zhang et al: Association between COX-2 rs2745557 polymorphism and prostate cancer risk: a systematic review and metaanalysis. BMC Immunology 2012 13:14.

\section{Submit your next manuscript to BioMed Central} and take full advantage of:

- Convenient online submission

- Thorough peer review

- No space constraints or color figure charges

- Immediate publication on acceptance

- Inclusion in PubMed, CAS, Scopus and Google Scholar

- Research which is freely available for redistribution

Submit your manuscript at www.biomedcentral.com/submit 